\title{
Determinants of Motivation of Workers of First Isabela Cooperative Bank Branches in the Province of Nueva Ecija in the Philippines
}

\author{
Ronald F. Felipe \\ Graduate School, Department of Business Administration \\ Nueva Ecija University of Science and Technology, Philippines \\ E-mail: gabrielarneil77@gmail.com \\ Kim Arvin D. Carreon \\ Graduate School, Department of Business Administration \\ Nueva Ecija University of Science and Technology, Philippines
}

Norwind B. Bontigao

Graduate School, Department of Business Administration

Nueva Ecija University of Science and Technology, Philippines

Mary Jane J. Romero

Graduate School. Department of Public Administration

Nueva Ecija University of Science and Technology, Philippines

Received: July 5, 2020 Accepted: October 26, 2020 Published: November 16, 2020

doi:10.5296/ber.v10i4.17300ＵRL: https://doi.org/10.5296/ber.v10i4.17300

\begin{abstract}
It is said that the most motivated workers can be found in the Banking and Insurance Industry. The study looks into the motivational factors affecting the satisfaction and performance of twenty workers from the three FICO Branches in the province of Nueva Ecija in the Philippines. Through the use of mixed methods of research and self-made questionnaire
\end{abstract}


designed to elicit the responses of the bank workers, the study found out that most of them are college graduates, are very satisfied with the offerings of the company, have been rendering their services for less than five years, and performs Above Expectations based on the company's recent evaluation. Based on the findings, it is suggested that: The motivational factors identified be reinforced for the worker's benefits; The management should consider conducting a regular survey to serve as platform where workers can voice out their needs and opinions for the further improvement of the workplace and existing policies, and to further uphold the workers' welfare; and Let the workers organize informal programs for stress management, recreations, trainings that they deem fit and necessary with due consideration to available resources and existing policies. Since the study is limited to the FICO Bank Branches in Nueva Ecija, it is also suggested that similar study be conducted in other locales and other bank branches.

Keywords: Motivation, Bank workers, Workplace, Benefits

\section{Introduction}

All organizations are created for specific purposes. Human resource is not only part of the process but plays important role towards the fulfilment of organizational objectives. Literatures further suggest that the success of organizations lies on their ability to motivate workers (Bergmann and Scarpello, 2001). Hence, the initiatives of various scholars to delve deeper into what motivates workers or the relationship between motivation, job performance, or other variables.

Interestingly, according to a study published in 2004, the most motivated workers can be found in the Banking and Insurance Industry (Storwall, 2004). FICO Bank or First Isabela Cooperative Bank, which is the focus of this study, provides fee-based services to the public and is among the prominent cooperative banks in the Philippines. Its thirty-five branches are strategically distributed across different provinces including Nueva Ecija (http://www.FICObank.com/corpoprofile.htm).

Tomer (2016) argues that motivation increases workers' job satisfaction and improves organizational performance. Worker retention is linked to the banks' strong human resource policies and perceived benefits. Other scholars believe that motivated workers contribute not only to the fulfilment of organizational objectives but also positively influence customer's satisfaction (Harter, Schmidt, and Hayes, 2002).

However, not all organizations are the same. They differ in approaches and workplace environment including workers' personal values and characteristics. This notion inspired the researchers to look into the determinants of motivation of workers of FICO Bank branches in the province of Nueva Ecija in the Philippines namely; FICO Bank Cabanatuan City, Municipality of Zaragoza, and Gapan City, all in the province.

The study primarily seeks to answer the following questions:

1. How may the profile of the respondents be described in terms of:

a. Highest educational attainment 
b. Length of service

2. How may the motivational factors be described in terms of:
a. Salary,
b. Benefits,
c. Medical assistance

3. How may the level of worker motivation be described based on:
a. Job Environment
b. Empowerment of Workers

4. Is there a significant difference between the level of motivation and workers' performance?

5. Is there a significant relationship between the workers' educational attainment and their level of motivation?

6. What recommendations may be offered based on the findings of the study?

\subsection{Hypotheses}

Ho: There is no significant difference between the level of motivation and workers' performance

Ho: There is no there a significant relationship between the workers' educational attainment and their level of motivation

\subsection{Research Paradigm}

The study used the Systems approach specifically the Input-Process-Output method to process and analyze the information and data collected.

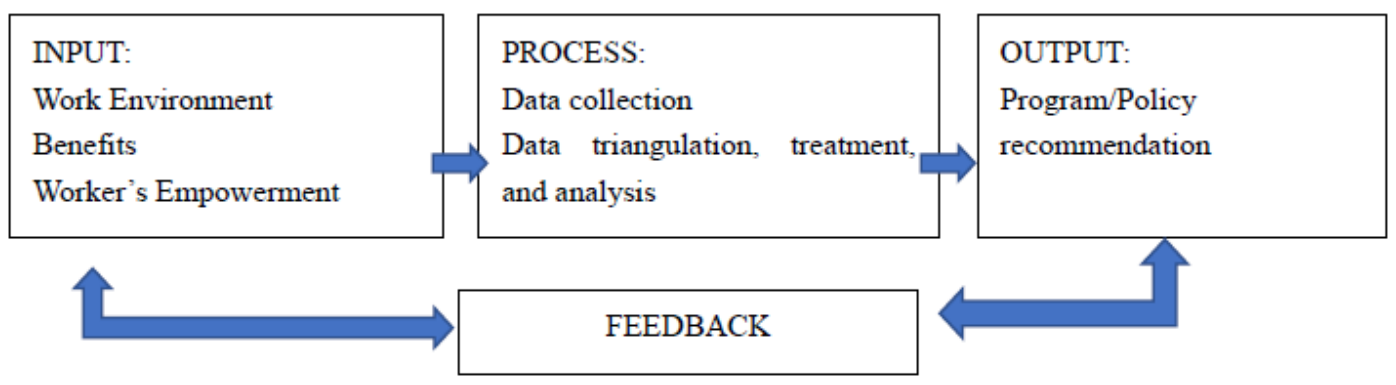

Figure 1. Research Paradigm

There are four variables serving as inputs to determine the motivation of the workers of First Isabela Cooperative Bank in the province of Nueva Ecija. They are the work environment, benefits and rewards, workers empowerment and recognition. These motivational variables 


\section{Mll Macrothink}

are presumed to improved workers' productivity. These inputs are processed (throughput). The determinants of motivation among the respondents were collected. analyzed and treated using statistical tools and methods to come up with the findings. Such findings are used to provide policy recommendations which formed part of a new input for further study and analysis.

\subsection{Conceptual Framework}

Figure 2 shows the conceptual framework of the study. The study argues that there are factors affecting employee motivation. The work environment has the effect of making the employees report for work every day. The conceptual frame is presented below, to wit;

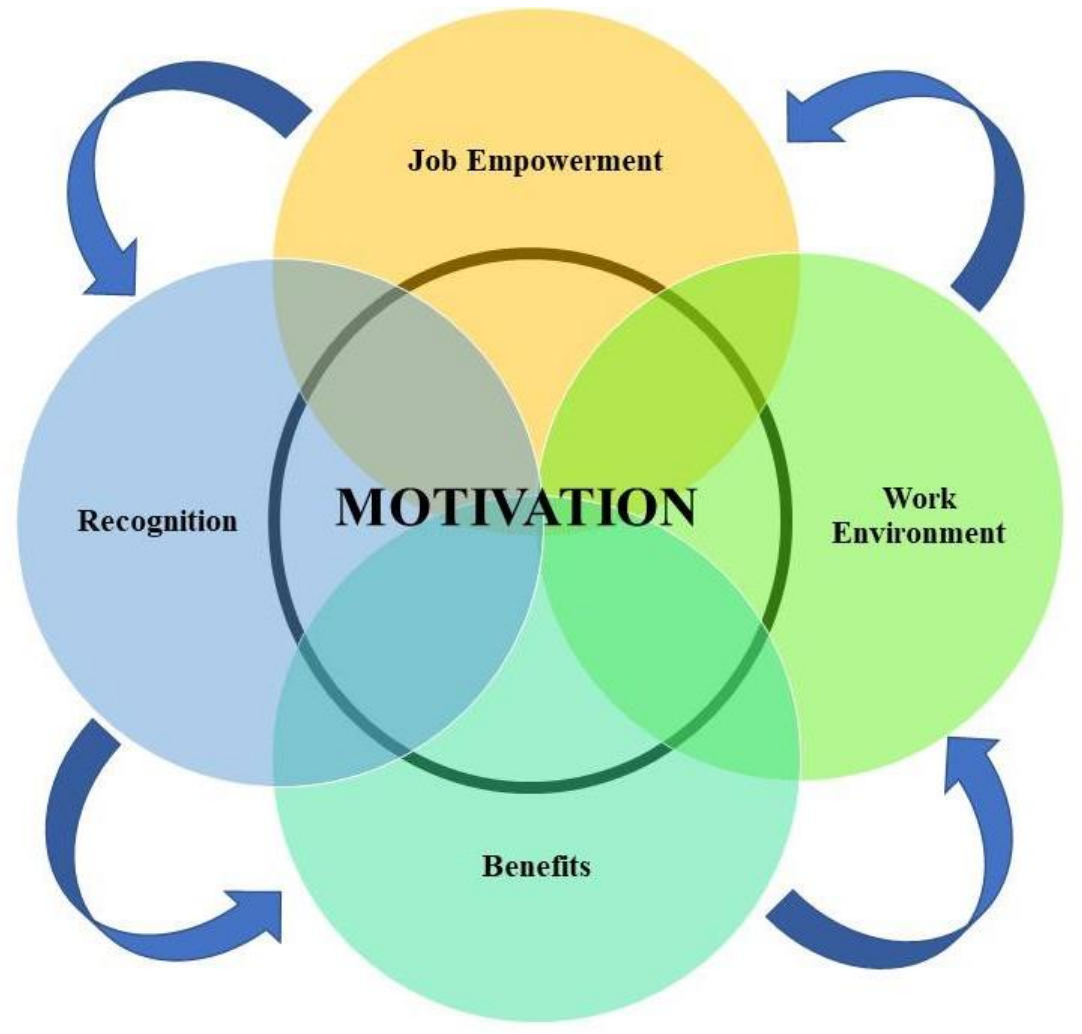

Figure 2. Conceptual Framework of the Study developed by the authors

If the work environment is not conducive to work, it affects the organizational productivity. It includes safety, security and health provisions to ensure that workers perform their tasks contributory to organizational productivity. The benefits are part of reward system that could promote and increase performance. They are motivators but when they are not present, the workers might be demotivated. That is the hygienic effect of benefits and rewards on motivation of workers. The study also argues that job empowerment is also a motivator. Independence and the higher level of control to one's function and tasks including the process, machineries and work outputs are important variables in improving job performance. Empowerment satisfies an employee natural inclination to contribute. The last motivator is recognition. Providing the employees feedback in the form of recognition is a sustainable 
means to maintain work motivation. All in all, when these factors are positively measured, employees' motivation is said to be high leading to higher organizational productivity.

\subsection{Theoretical Framework}

Among the long lists of existing motivational models, the study was anchored on Herzberg's Two-Factor Theory. Through this widely-known theory, Herzberg asserts that individuals are affected by motivators and hygiene factors. As adapted in this study, motivators are those which are intrinsic or based on the personal preference and outlook of workers. These include responsibility, opportunity for personal and professional growth, challenging work, achievement, and recognition. Whereas, hygiene factors are those related to the work environment such as pay, interpersonal relationship with peers and supervisors, working conditions, policies, status, and job security.

Accordingly, the theory guides the analysis of the data and of the variables included in the study. It has been considered in proving or disproving whether satisfying the needs for motivation leads to higher level of motivation and job performance among workers.

To exemplify, low level of hygiene factors leads to low satisfaction; and higher motivating factor means higher job satisfaction.

\section{Method}

\subsection{Research Design}

The study used mixed methods of research. It used a combination of self-made questionnaire triangulated using available data. The collected information was further compared and contrasted to the chosen motivation theory and the literatures available in the field.

The survey questionnaire was grouped into two. The first part elicits responses about the demographic profile of the respondents. Whereas the second part focuses on the general information regarding the factors affecting worker's motivation and professional growth needs. To determine the perception and level of motivation of the workers, a four-point Likert-type questionnaire was employed.

The questionnaires and guide questions were administered randomly to the twenty workers (seven from each branch) of FICO Bank Nueva Ecija Branches with the permission of the bank's authorized personnel. The participation of authorities is only to ensure that the data gathering procedures are in accordance with the institution's protocol and not in the selection of respondents.

\subsection{Analysis}

A total of twenty workers of FICO Bank based in the province of Nueva Ecija willingly participated in the study. The number is representative of the entire population of the bank workers. In the Philippines, it is typical for institutions like the one involved in the study to have small number of workers. The results were statistically treated using measures of central tendency and presented in tabular form. The mean responses are numerically and verbally interpreted as: 3.26-4.0 (Very Satisfied); 2.51-3.25 (Satisfied); 1.76-2.50 (Unsatisfied); and 


\section{1) Macrothink}

1.0-1.75 (Very Satisfied).

\subsubsection{Educational Attainment}

The study of $\mathrm{Ng}$ and Feldman (2009) looked into the effects of educational attainment on motivation and job performance. They found out that the former helps build stronger social ties. Meanwhile, based on the respondents' demographics (Table 1), majority (90\%) are college graduates.

Table 1. Summary of the Highest Educational Attainment of FICO Bank Workers

\begin{tabular}{|l|l|}
\hline Highest Educational Attainment & Frequency \\
\hline College Undergraduate & 1 \\
\hline College Graduate & 18 \\
\hline Master's Degree & 1 \\
\hline Doctorate Degree & 0 \\
\hline Total & $\mathbf{2 0}$ \\
\hline
\end{tabular}

The findings validate the idea that similar to other Banking institutions, FICO Bank follows the minimum qualification standard in hiring workers. Nonetheless, it can be noted that one worker (5\%) of the sample opted to obtain Master's Degree for personal and professional growth even if it is not required by the company.

\subsubsection{Length of Service}

The study also collected information regarding the workers' length of service in the institution which is summarized in Table 2.

Table 2. Summary of the Length of Service of FICO Bank Workers

\begin{tabular}{|l|l|}
\hline Length of Service & Frequency \\
\hline $0-5$ years & 14 \\
\hline 6 years and above & 6 \\
\hline Total & $\mathbf{2 0}$ \\
\hline
\end{tabular}

The table revealed that $30 \%$ (6 out of 20 workers) of the respondents have already rendered more than five years in service while $70 \%$ (14 out of 20) of them served for less than 5 years. It can be noted that workers have been with the company for many years now. A positive finding since the institution was able to keep its workers and have them render their services for long period of time.

The findings coincide with that of Sarker, Crossman, and Chinmeteepituck (2003) who also found a correlate between the employees' length of stay and satisfaction level. 


\subsubsection{Motivation Factors}

Dartey-Baah (2010) believes that a satisfied and motivated work force can help sustain commitment and productivity. In his work, he cited Locke's (1976) lists of workers' characteristics that affect level of satisfaction such as demographic factors (age, sex, education, position, and length of service). Similarly, Cranny, Smith, and Stone (1992) foster the idea that the workers' satisfaction leads to them feeling motivated, having lesser desire to change work, and exhibiting increased willingness to contribute to the productivity of the company.

The study looked into the factors which might increase the level of motivation of the workers. Primarily, it analyzed the perception of the workers as to the benefits they receive from the company and whether these benefits affect their decision to stay and to continuously render their services to the institution.

The benefits they are receiving and the mean responses are presented in the Table 3 that follows:

Table 3. Summary of the benefits received by the FICO Bank Workers

\begin{tabular}{|l|l|}
\hline Benefits received by workers & Mean \\
\hline 1. Bonus and allowance & 3.70 \\
\hline 2. Incentives & 3.70 \\
\hline 3. Higher benefits compared to other similar institutions & 3.70 \\
\hline 4. Government mandated benefits such as PAG-IBIG, SSS and PhilHealth & 3.80 \\
\hline 5. Medical assistance in the form of hospitalization package & 3.65 \\
\hline 6. Dental services & 3.80 \\
\hline 7. Overtime pay & 3.60 \\
\hline 8. 13 ${ }^{\text {th }}$ month pay & 3.85 \\
\hline 9. Loan privileges & 3.65 \\
\hline 10. Separation/retirement pay & 3.35 \\
\hline 11. Salary increase & 3.55 \\
\hline Grand Mean & $\mathbf{3 . 6 7}$ \\
\hline
\end{tabular}

The table revealed the grand mean of 3.67 which is verbally described as Very Satisfied. As can be gleaned from the table, the workers are pleased about the company providing $13^{\text {th }}$ month pay, mandated benefits such as PAG-IBIG, SSS, and PhilHealth, and dental services as reflected in the mean scores of 3.85 and 3.80 respectively. Also, all of them agreed that receiving benefits listed in the table above positively affects their satisfaction and increases their motivation to stay in the company, do their job well, and serve the clienteles well.

\subsubsection{Work Environment}

When asked about work environment, the respondents agreed that they are motivated by the presence of enough work space (3.70 mean score), secure environment and free coffee (both 
with 3.60 mean scores), verbally interpreted as Very Satisfactory.

The summary of the responses is depicted in the Table 4 that follows:

Table 4. Summary of the Workers' insights about their Work Environment

\begin{tabular}{|l|l|}
\hline Work Environment & Mean \\
\hline 1. Secure Environment & 3.60 \\
\hline 2. Enough work space & 3.70 \\
\hline 3. Free lodging & 3.25 \\
\hline 4. Free coffee & 3.60 \\
\hline 5. Free candies & 3.50 \\
\hline Total & 17.65 \\
\hline Grand Mean & 3.53 \\
\hline
\end{tabular}

Worth noticing is that the workers are satisfied with the free lodging offered by the institution. However, only few avails of the program because they prefer going home on a daily basis considering that their residences are located just within the province. The item "secure environment "is also at the range of satisfied as this reveals how the company provides protection and security for the workers to become productive. This finding is contrary to the findings of the study in the same province but of different industry where sexual harassment in the workplace (Gabriel and Panahon , 2017) has the potential to disturb workplace security and safety which might result in student demotivation.

\subsubsection{Job Empowerment}

It is said that the productive workers are the empowered ones (Huczynski and Buchanan, 1991). Part of the workplace enrichment is empowering workers by including them in the decision-making process and other activities of the institution as shown in Table 5.

Table 5. Summary of workers' insights on how their work empowers them

\begin{tabular}{|l|l|}
\hline Job Empowerment & Mean \\
\hline 1. The company allows workers to be part of the decision-making process & 3.20 \\
\hline 2. The company boosts worker's self confidence & 3.45 \\
\hline 3. The company provides benefits that promotes higher job satisfaction & 3.45 \\
\hline Grand Mean & 3.37 \\
\hline
\end{tabular}

Based on the workers' responses, they feel empowered as reflected in the 3.37 mean score (Very Satisfactory) in Table 5. Aside from having relevant education, the trainings provided by the company made them more confident in their jobs. The benefits offered by the company makes them feel motivated. And the company allowing them to be part of the decision-making process makes them feel valued and essential for the continuous development of the institution they are serving. Indeed, the findings support the idea of 
Dester (2007) who believes that involvement is an important ingredient to enhance employee productivity and towards development of highly interactive workforce. However, such finding is different from the findings of the study of Alcantara, Claudio and Gabriel, (2017) where workplace bullying demoralizes employees in a hospital industry and disturbs peace and security of the school premises leading to basic education teachers' negative perception on some behaviors in education industry (Gabriel and Gabriel, 2016), in the same province.

\subsubsection{Recognition}

Achievement, recognition, and responsibility are considered as high-level needs that increases satisfaction and add motivation to workers (Baldamus, 1961; Mottaz, 1987; Martin, 2005). They are ways of giving employees certain status within the organization or reward for job well done. But for Savery (1996), workers who adjusted their work values to that of the workplace and exerted much effort yet, receive little or no recognition tend to experience dissatisfaction and are likely to leave the organization

The lists of recognition usually provided to the workers for their satisfactory works is presented in Table 6 .

Table 6. Summary of the recognition usually provided to the workers for their satisfactory works

\begin{tabular}{|l|l|}
\hline Recognition & Mean \\
\hline 1. Loyalty Award & 3.55 \\
\hline 2. Incentives & 3.75 \\
\hline 3. Formal recognition witnessed by public/group of people & 3.50 \\
\hline 4. Expressed through kind gestures, formal communication & 3.35 \\
\hline 5. Verbally praised & 3.35 \\
\hline Grand Mean & 3.50 \\
\hline
\end{tabular}

The data above shows that the workers are motivated by the recognition they receive from either the company or the managers. Majority (3.75) mentioned that they are highly motivated by incentives in the form of cash, gifts, and other perks; and in receiving Loyalty Award (3.55) for being with the company for long period of time; and formal recognitions awarded to them in front of co-workers and other colleagues during company events (3.50 mean score). Others even appreciate the kind gestures, letters received from the management (3.55) and simple praise and "thank you" or good job uttered by their supervisors and peers.

\subsubsection{Motivational Factors and Workers' Performance}

Literatures suggest that motivational factors influence workers' performance. Crow and Hartman (1995) mentioned that reducing dissatisfaction and increasing workers' motivation improve their performance. The findings are similar with that of Tietjen and Myers (1998). However, they also consider the contribution of factors identified by Herzberg in his theory of $\mathrm{X}$ and $\mathrm{Y}$ related to the work itself and other sources of satisfaction (achievement, recognition, advancement and growth) and potential sources of dissatisfaction policy and 


\section{Ml Macrothink}

Business and Economic Research ISSN 2162-4860 2020, Vol. 10, No. 4

administration, supervision, salary, interpersonal relations, working conditions, status and security.

These factors were reflected and cross examined in the study using the data collected from the respondents as reflected in Table 7.

Table 7. Summary of Mean of the Motivational Factors, Level of Satisfaction and Performance Evaluation of each Worker

\begin{tabular}{|c|c|c|c|c|c|c|c|}
\hline Worker & Benefits & Environment & Empowerment & Recognition & $\begin{array}{l}\text { Total } \\
\text { Mean }\end{array}$ & Interpretation & $\begin{array}{l}\text { Performance } \\
\text { Evaluation }\end{array}$ \\
\hline 1 & 3.73 & 3.40 & 3.00 & 3.00 & 3.28 & VS & $\mathrm{ME}$ \\
\hline 2 & 3.73 & 4.00 & 3.33 & 4.00 & 3.77 & VS & $\mathrm{ME}$ \\
\hline 3 & 3.45 & 3.00 & 3.00 & 3.00 & 3.11 & $\mathbf{S}$ & ME \\
\hline 4 & 3.55 & 3.60 & 3.00 & 3.40 & 3.39 & VS & $\mathrm{ME}$ \\
\hline 5 & 3.00 & 3.00 & 3.00 & 3.00 & 3.00 & $\mathbf{S}$ & $\mathrm{AE}$ \\
\hline 6 & 4.00 & 3.20 & 3.67 & 4.00 & 3.72 & VS & $\mathrm{AE}$ \\
\hline 7 & 4.00 & 3.40 & 4.00 & 4.00 & 3.85 & VS & $\mathrm{AE}$ \\
\hline 8 & 3.82 & 3.40 & 4.00 & 4.00 & 3.80 & VS & $\mathrm{ME}$ \\
\hline 9 & 4.00 & 3.40 & 4.00 & 3.60 & 3.75 & VS & $\mathrm{AE}$ \\
\hline 10 & 3.00 & 3.20 & 3.00 & 3.00 & 3.05 & $\mathbf{S}$ & $\mathrm{AE}$ \\
\hline 11 & 3.91 & 3.80 & 3.33 & 3.60 & 3.66 & VS & $\mathrm{AE}$ \\
\hline 12 & 4.00 & 3.80 & 3.67 & 3.60 & 3.77 & VS & $\mathrm{AE}$ \\
\hline 13 & 4.00 & 3.80 & 3.67 & 3.60 & 3.77 & VS & $\mathrm{AE}$ \\
\hline 14 & 3.45 & 4.00 & 3.67 & 3.40 & 3.63 & VS & $\mathrm{AE}$ \\
\hline 15 & 3.00 & 4.00 & 3.00 & 3.80 & 3.45 & VS & $\mathrm{AE}$ \\
\hline 16 & 4.00 & 2.80 & 3.00 & 3.00 & 3.20 & $\mathbf{S}$ & $\mathrm{AE}$ \\
\hline 17 & 3.18 & 3.20 & 1.33 & 2.60 & 2.58 & $\mathbf{S}$ & $\mathrm{AE}$ \\
\hline 18 & 4.00 & 3.80 & 4.00 & 3.40 & 3.80 & VS & $\mathrm{ME}$ \\
\hline 19 & 4.00 & 3.80 & 3.67 & 4.00 & 3.87 & VS & $\mathrm{AE}$ \\
\hline 20 & 3.55 & 4.00 & 4.00 & 4.00 & 3.89 & VS & $\mathrm{AE}$ \\
\hline
\end{tabular}

Legend: VS = Very Satisfied S = Satisfied ME = Meets Expectations AE = Above Expectations

The workers are Very Satisfied with all the areas measured (benefits, work environment, job empowerment, and recognition). They also perceive that their job satisfaction equates to good performance as reflected in Meets Expectation and Above Expectation verbal interpretation of their performance as evaluated by the supervisors. As can be gleaned from the table, 10 out of 20 workers (50\%) received performance evaluations of Above the Expectations (AE) from the supervisors and at the same time said that they are Very Satisfied (VS) with their work. Meanwhile, there are 4 out of 20 who received Above the Expectations (AE) evaluation yet are only Satisfied (S) in their work.

The findings also support Sison's (2008) points that work environment, empowerment, and recognition inspire workers to work effectively. Corollary, leadership competencies of millennial managers are instrumental to the motivation of older employees in a government owned and controlled corporation. The areas identified are: building good impression and rapport or soft skills in leadership, strong sense of respect, reverse mentoring, delegation of tasks, and the ability to handle expectations and performance (Gabriel, Alcantara, \& Alvarez, 
2020).

\subsubsection{Comparison of Workers' Level of Motivation and Performance Evaluation}

The data gathered was further analyzed using the analysis of variance (ANOVA) to test the significant difference between the motivation factors and the performance evaluation of the workers. With the computed F-value equal to 25.89 which is higher than the critical value of $\mathrm{F}$ which is 4.38 , the formulated null hypothesis was disproved. This data therefore means that the motivational factors received by the workers greatly affects their performance towards their work.

\subsubsection{Educational Attainment of Worker and Level of Motivation and Satisfaction}

Table 9. Comparison of Workers' Level of Motivation and their Educational Attainment

\begin{tabular}{|l|l|l|}
\hline $\begin{array}{l}\text { Worker's Level of Motivation and } \\
\text { their Educational Attainment }\end{array}$ & Frequency & Percentage \\
\hline Very Satisfied / With Master's Degree & 1 & $5 \%$ \\
\hline Very Satisfied / College Graduate & 13 & $65 \%$ \\
\hline Very Satisfied/College Undergraduate & 1 & $5 \%$ \\
\hline Satisfied/College Graduate & 5 & $25 \%$ \\
\hline Total & 20 & $100 \%$ \\
\hline
\end{tabular}

The table shows that the educational attainment of the workers does not affect their motivation and satisfaction towards their work since there are 15 out of 20 who were very satisfied in their work regardless of being a college graduate, a college undergraduate or a graduate with Master's degree. Positively, $65 \%$ of the workers were very satisfied with their current job as they happen to be college graduates with degrees relevant to the job.

\subsubsection{Length of Service and Motivation}

The table shows the comparison between the motivation and satisfaction of the workers and their length of service.

Table 10. Comparison of Workers' Level of Motivation and their Length of Service

\begin{tabular}{|l|l|l|}
\hline Worker's Level of Motivation and their Length of Service & Frequency & Percentage \\
\hline Very Satisfied / 6 Years and above & 6 & $30 \%$ \\
\hline Very Satisfied / 0-5 years & 9 & $45 \%$ \\
\hline Satisfied/6 Years and above & 2 & $10 \%$ \\
\hline Satisfied/0-5 years & 3 & $15 \%$ \\
\hline Total & 20 & $100 \%$ \\
\hline
\end{tabular}

Based on the data on the table, 9 out of 20 workers (45\%) were very satisfied in their work as 
they have served the company between $0-5$ years; while 6 out of 20 or $30 \%$ of workers were also satisfied serving the company for more than 5 years. This means that most of the workers were very satisfied with the work, their status, and the company that is why they opt to serve the company and its clienteles for many years.

\section{Conclusion and Recommendation}

This study focused on identifying the motivational factors that affects the performance of the workers of FICO Bank Nueva Ecija Branches. It includes the analysis of whether the identified factors affect workers' performance.

In summary, the study found out that majority (90\%) of the workers surveyed are College Graduates and that the company accepts this as part of the minimum qualification standards. Most of them are with the company for less than five years at the time of data gathering and are either satisfied or very satisfied with their present work and workplace, and the benefits they are getting from the company.

Based on the findings of the study, the following conclusions were drawn: 1) It is important to satisfy the workers by giving them incentives as motivational factors to fulfill their work; 2) Giving recognitions and rewards served as essential factors in motivating the workers; 3 ) It is essential to identify the needs as well as the factors that will keep the workers motivated to work; 4) The identified motivational factors should be provided and further improved in order for the workers to feel satisfied as they will aspire to serve the company for more years.

\section{Recommendations}

Based on the conclusions drawn, the following recommendations are offered: 1) The motivational factors identified should be reinforced for the worker's benefits; 2) The management should consider conducting a regular survey to serve as platform where workers can voice out their needs and opinions for the further improvement of the workplace and existing policies, and to further uphold the workers' welfare; 3) Let the workers organize informal programs for stress management, recreations, trainings that they deem fit and necessary with due consideration to available resources and existing policies.

\section{References}

Alcantara, G., Claudio, E., \& Gabriel, A. (2017). Prognosis of Workplace Bullying in Selected Health Care Organizations in the Philippines. Open Journal of Social Sciences, 5, 154-174. https://doi.org/10.4236/jss.2017.59012

Baldamus, W. (1961). Efficiency and Effort. Tavistock Publications Ltd, London.

Bergmann, T. J., \& Scarpello, V. G. (2001). Compensation Decision Making (4th ed.). Fort Worth: Harcourt, Inc.

Cranny, C. J., Smith, P. C., \& Stone, E. F. (Eds.) (1992). Job Satisfaction: How people feel about their jobs and how it affects their performance. New York: Lexington Books.

Crow, S. M., \& Hartman, S. J. (1995). Can’t get no satisfaction. Leadership \& Organization 
Development Journal, 16, 34-8. https://doi.org/10.1108/01437739510089085

Dartey-Baah, K. (2010). Job satisfaction and motivation: Understanding its impact on employee commitment and organisational performance. Academic Leadership. pp. 8.

Dester (2007). Management Lending People and Organizations in the 1st Century. USA.

Gabriel, A. G., Alcantara, G. M., \& Alvarez, J. D. G. (2020). How Do Millennial Managers Lead Older Employees? The Philippine Workplace Experience. SAGE Open. https://doi.org/10.1177/2158244020914651

Gabriel, A. G., \& Panahon, H. P. (2017). Drawing the Demarcation Line: An Analysis of Sexual Harassment in Selected Learning Institutions in Nueva Ecija, Philippines Using Blumer's Interactionism Model. Open Access Library Journal, 4, e3328.

http://dx.doi.org/10.4236/oalib.1103328

Gabriel, A. G., \& Gabriel, J. P. (2016). Basic Education Teachers and Workplace Bullying in the Philippines: An Organizational Prism. Imperial Journal of Interdisciplinary Research, 2(10).

Harter, J. K., Schmidt, F. L., \& Hayes, T. L. (2002). Business-unit-level relationship between worker satisfaction, worker engagement, and business outcomes: A meta-analysis. Journal of Applied Psychology, 87(2), 268-279. https://doi.org/10.1037/0021-9010.87.2.268

Huczynski, A. A., \& Buchanan, D. A. (1991). 'Organizational Behaviour'-An introductory text (2nd Ed.). Prentice Hall (UK) Ltd. pp. 436-466.

Locke, E. A. (1976). The nature and causes of job satisfaction. In M. D. Dunnette (Ed.), Handbook of Industrial and Organizational Psychology. Chicago, Ill: Rand-McNally College Publishing Co; chap 30.

Martin, J. (2005) Organizational Behaviour and Management (3rd ed.). Thomson learning London. pp. 420-466

Mottaz, C. (1987). Gender differences in work satisfaction, work-related rewards and values, and the determinants of work satisfaction. Human Relations, 39, 359-78.

https://doi.org/10.1177/001872678603900405

Porter, T., Riesenmy, K., \& Fields, D. (2016). Work environment and employee motivation to lead: Moderating effects of personal characteristics. American Journal of Business, 31, 66-84. https://doi.org/10.1108/AJB-05-2015-0017

Sarker, S., Crossman, A., \& Chinmeteepituck, P. (2003). The relationships of age and length of service with job satisfaction: An examination of hotel employees in Thailand. Journal of Managerial Psychology, 18, 745-758. https://doi.org/10.1108/02683940310502421

Savery, L. K. (1996). The congruence between the importance of job satisfaction and the perceived level of achievement. Journal of Management Development, 15, 18-27. https://doi.org/10.1108/02621719610120110 


\section{Macrothink}

Business and Economic Research

ISSN 2162-4860

2020, Vol. 10, No. 4

Sison, P. (2008). Personal Administration. Rex Bookstore, Quezon City, Philippines.

Storwall, A. (2004). Banken bästa jobbet. Svenska Dagbladet. [Online] Available:

http://www.svd.se/dynamiskt/naringsliv/did_8158734.asp

Tietjen, M. A., \& Myers, R. M. (1998). Motivation and job satisfaction. Management Decision, 36, 226-31. https://doi.org/10.1108/00251749810211027

Tomer, S. (2016). Analysis of worker motivation in banking sector. International Journal of Applied Research, 2(11), 392-395.

\section{Copyright Disclaimer}

Copyright for this article is retained by the author(s), with first publication rights granted to the journal.

This is an open-access article distributed under the terms and conditions of the Creative Commons Attribution license (http://creativecommons.org/licenses/by/4.0/). 